\title{
How likely am I to return home? A study of New Zealand self-initiated expatriates
}

\begin{abstract}
Our study contributes to the research domain of self-initiated repatriation, focusing on the drivers of SIEs' intention to repatriate. We examine the impact of selected individual characteristics (gender, ethnicity, international experience), contextual factors (spouse job availability, nature of networks, host country location) and the established home country pull factors (economic opportunities, life style and relational considerations) on SIE intention to repatriate. We also examine the moderating effects of gender and international experience. Based on a sample of 248 New Zealand SIEs, the findings support the role of the established home country pull factors, but a number of the additional contextual factors and individual characteristics of SIEs, as well as the moderation effects of gender and international experience represent new findings and offer contributions to the SIE repatriation literature.
\end{abstract}

Keywords: Self-initiated expatriates, repatriation, New Zealand

\section{Please cite this article as}

Lindsay, V., Sharma, R. R., \& Rashad, H. (2019). How likely am I to return home? A study of New Zealand self-initiated expatriates. Asia Pacific Journal of Human Resources, 57, 57-84. doi: https://doi.org/10.1111/1744-7941.12148 


\section{Introduction}

The increased geographic mobility of employees and global circulation of human talent made possible by globalisation bring significant advantages to countries, but also challenges to those which face shortages of skilled people, as they move abroad seeking better opportunities. As a result, considerable organisational and government attention has centred on finding ways to retain the best talent and attract back those who have left. Professionally, a person who travels abroad to work is termed an expatriate, defined as: "an individual who moves to another country while changing their dominant place of residence and executes legal work abroad." (Andresen, Bergdolt, Margenfeld and Dickmann, 2014, p.2308).

Expatriates are of two main types (Suutari and Brewster, 2000; Biemann and Andresen, 2010): those assigned by their home country organisation (organisational/corporate expatriate $-\mathrm{OE}$, or assigned expatriate $-\mathrm{AE}$ ), and those who independently initiate their move to work in another country (self-initiated expatriate - SIE). For the purpose of this paper, we will be using the term $\mathrm{AE}$ to denote assigned/organisational/corporate expatriates. SIEs form the greatest number of expatriates, and have different motivators to AEs (Andresen et al, 2014). It is clear from the literature that expatriates repatriate for different reasons (Doherty, Dickmann and Mills, 2011). Repatriation is the return of an expatriate to his or her home country, either with the expatriating organisation (for AEs), or by self-initiation (for SIEs) (Tharenou and Caulfield, 2010). Repatriation is an important element of the entire expatriation-repatriation cycle, which starts with initiation of the assignment, followed by preparations for expatriation, adjustment to the foreign culture and workplace, preparations for return to the home country, and repatriation itself (Stahl, 1998).

According to King (2000, p 8), self-initiated repatriation occurs when "people [SIEs] return to their country or place of origin after a significant period in another country" (cited in Tharenou and Caulfield, 2010, p1010). As noted by Altman \& Baruch (2012, p. 244), SIE 
repatriation (compared with SIE expatriation) is "more chaotic in context and circumstance", suggesting that the determinants and interacting variables influencing repatriation require further elucidation. Research on repatriation has tended to focus on returning AEs, (Begley, Collings and Scullion, 2008), with far less on SIEs repatriation (Doherty, Richardson and Thorn, 2013), highlighting the need for more research in this area. Some research has investigated the outcomes of SIE repatriation (e.g. Begley et al, 2008); but, with some notable exceptions (e.g. Baruch, Budhwar and Khatri, 2007; Cao, Hirschi and Deller, 2014; Jackson et al 2005; Tharenou and Caulfield, 2010), far less has been reported on what influences an SIE's intention to return home or stay in their host country.

Following these researchers of SIE repatriation, we focus on the SIE's intention to return as our outcome variable, since we specifically seek an understanding of what influences the SIE before the act of repatriation occurs. This is based on the assumption that intention is strongly correlated with action (Fishbein and Ajzen, 1975); thus, it is likely that the factors that influence intention to return home will lead directly to repatriation itself. Intention to repatriate occurs when a professional, having had an expatriate experience, is motivated to return to his/her home country after a period of years away (Lidgard and Gilson, 2002). In their longitudinal study of Australian expatriates, Tharenou and Caulfield (2010) showed that intention to repatriate predicts actual repatriation, validating the reliance of studies that focus on intention as the outcome variable.

Some studies investigating intention to repatriate have drawn on Toren's (1976) 'push-pull' view, derived from the job turnover literature, highlighting both push and pull factors relating to the home and host countries concerned (Baruch et al, 2007; Tharenou and Caulfield, 2010; Junaimah and Yusliza, 2011). Either, or both, host country push and home country pull factors may lead to repatriation by SIEs (Tharenou and Caulfield, 2010). For example, expatriates may be pushed to go home by less favourable factors (such as the loss of 
a job) in the host country (host country push), or may be pulled by factors relating to the home country, such as family and lifestyle (Carr, Inkson and Thorn, 2005). The interaction of these factors highlights the complexity and multi-dimensionality of influences on SIE repatriation, which, as yet, are not well understood in the research community.

Drawing from the extant literature, we develop a number of hypotheses concerning three home country pull factors, and the selected contextual and individual characteristics. First, the three home country pull factors used are economic opportunities, lifestyle, and relational considerations. These have been reported in some of the few existing studies on SIE repatriation (e.g. Jackson et al, 2005, Tharenou and Caulfield, 2010). Secondly, Additional contextual factors examined in this study include social versus work-related networks in the host country, spouse job availability in the home country, and location of host country. Out of these three factors, the first two factors have been identified as influences in SIE expatriation and AE repatriation, but their role in SIE repatriation is not clear. Further, host country location is included as a contextual factor as cross-cultural adjustment issues in a host country may impact the success of an expatriate assignment (Begely et al, 2008). Finally, the role of individual characteristics of SIEs is important to consider, since these may directly or indirectly influence decision-making about repatriation. Individual characteristics included in this study are ethnicity, gender, international experience, and age. We note that little, if any, work has been conducted on these in the context of SIE repatriation, or in terms of their potential interaction effects on key relationships involved in intention to repatriate.

Our study contributes to the literature by responding to calls (Al Ariss \& CrowleyHenry, 2013; Doherty et al, 2013; Guo, Porchitz and Alves, 2013) for more research to add to the existing small body of literature on SIE repatriation. More specifically, we provide evidence that, apart from the established home country pull factors (economic opportunity, lifestyle and relational considerations) additional contextual factors and individual 
characteristics of SIEs influence the SIE's intention to repatriate. Further, we show the interactions of gender and international experience with two home country pull factors (economic and relational considerations) and repatriation intention.

We conduct our study in the context of New Zealand SIEs living and working in another country at the time of the study. New Zealand is an ideal context for studying repatriation motives of expatriates (Jackson, Carr, Edwards et al, 2005), since it has the highest proportion of highly skilled professionals living abroad amongst the OECD countries (National Business Review, 2010). In the case of New Zealand, it results largely from an insufficient industry base or structure to support the career development of high numbers of trained professionals, who often prefer to take up more economically attractive opportunities overseas (Jackson et al, 2005). While not generalizable to other countries, it is possible that similar influences may exist for other small developed economies, which share the issue of talent loss and need for repatriation of their professionals living and working abroad.

The rest of the paper is organised as follows. The next section presents relevant theory and hypotheses development, followed by a section describing the research methods and data utilised in the study. The subsequent sections present the results and discussion, followed by the conclusions from the study, which include implications for practice and future research, as well as limitations of the study. 


\section{Theory and Hypotheses Development}

In a study of New Zealand expatriates, Carr et al (2005) identified several push and pull factors influencing their decision to repatriate. Push factors (towards the host country) included economic, political, and career-related factors, while pull factors (towards home) included culture, family and lifestyle. Lifestyle and family have been shown to be one of the strongest home country pull factors in New Zealand and Australian studies (e.g. Hugo, Rudd and Harris, 2003; Inkson, Carr, Edwards et al, 2004). The most common host country pull factors (towards the host country) tend to be opportunities relating to career, business, profession, and finance. On the other hand, host country push factors (towards home) include lack of opportunities, and lack of adjustment by the spouse in the host country (Tharenou and Caulfield, 2010).

\section{Main home country pull factors}

\section{Economic opportunities}

The conceptual logic for the inclusion of economic drivers as a main variable influencing intention to repatriate is found in the existing literature. Economic drivers for SIEs, both in expatriation and repatriation decisions, are very strong (Kazlauskienè \& Rinkevičius, 2006; Ushkalov \& Malakha, 2001). This is usually reflected in the literature as a host country pull factor for expatriation, whereby the host country offers more favourable economic opportunities than the SIE's home country; conversely, low economic opportunities in the home county may be viewed as a home country push factor (Carr et al, 2005). As long as differential economic opportunities between home and host country persist in favour of the host country, they remain a strong factor discouraging repatriation (Richardson and McKenna, 2006). If the difference reverses in favour of the home country, economic opportunity will become a home country pull factor. Either way, the SIE will choose the most 
favourable economic location. Given this, we would expect that, if an SIE perceives economic opportunities in New Zealand to be better than in the host country, he/she will be encouraged to repatriate.

H1: There is a positive relationship between the perceived pull of economic opportunities in the home country and NZ SIEs' intention to repatriate.

\section{Lifestyle}

Lifestyle has been shown to be instrumental in the decisions of individuals to expatriate (Inkson et al, 2004; Sriskandarajah and Drew, 2006; Selmer and Lauring, 2010; Thorn, 2009). Lifestyle is reflected in aspects such as quality leisure time, sports, and recreational opportunities (Jackson et al, 2005). Confirming its importance, Tharenou and Caulfield (2010) found that lifestyle instrumentality was positively related to SIEs' intention to repatriate. Lifestyle instrumentality "explains the extent to which expatriates believe that repatriation will offer lifestyle benefits (e.g., the lifestyle itself, the physical environment, friendship, and a place to raise children)" (p. 1013). Thus, when expatriates perceive that lifestyle opportunities are greater in their home country, they will have a stronger intention to repatriate.

H2: There is a positive relationship between the perceived pull of lifestyle in the home country and NZ SIEs' intention to repatriate.

\section{Relational considerations}

Relational considerations based on family, relatives and friends are usually weighed against work and career related concerns in the repatriation decision. It is well established that expatriates are pulled towards home due to family related factors in the home country, such as their home-based grown-up children, grand-children, spouse, or caring for aging relatives 
(Inkson et al., 2004; Hugo et al, 2003; Tharenou and Caulfield, 2010). Preserving family units is often a high priority in the decision of expatriates to return home, as is providing a secure upbringing and education for their children who relocated to the host country with them (Inkson et al., 2004; Thorn, 2009).

With regard to friendships, an expatriate who feels "outsiderness" in the host country, due to lack of close friendships, may be more attracted to return home than to staying longterm in the host country (Richard and Zikic, 2007, p.174), even though they may have sound career prospects (Inkson and Richardson, 2010). Overall, the extant research suggests that relational considerations (family and friends) are important drivers for expatriates to return home. In the case of New Zealand expatriates, this is a particularly so, as they perceive the country to be a great place to bring up their children, and the pull of family and friendship ties is also strong. Thus, expatriates with close family and friendship ties in their home country are more likely to repatriate.

H3 There is a positive relationship between the perceived pull of relational considerations in the home country and NZ SIEs' intention to repatriate.

\section{Contextual factors}

A range of contextual factors have been shown to influence expatriation and repatriation decisions across both SIE and AE studies, but with a concentration on AEs. In order to examine the influence of contextual factors (Fatimah, Yusliza, and Surienty, 2013; Doherty et al, 2011; Al Ariss and Crowley-Henry, 2013) on repatriation intention in our study, we selected those factors that have been investigated in SIE expatriation literature, but little studied in SIE repatriation research. We justify this on the basis that expatriation and repatriation can be viewed as interrelated parts of the same phenomenon (Altman and Baruch, 
2012). These factors are SIE involvement in social vs work-related networks in the host country, spouse job availability in the home country, and host country location.

\section{Social and work-related networks in the host country}

As the importance of career as a driver of self-initiated expatriation has been recognised (Doherty \& Dickmann, 2012), recent work has suggested contemporary career theory as an appropriate theoretical base for SIE studies (Doherty, Richardson and Thorn, 2013a). Central to career theory and boundaryless careers (Arthur and Rousseau, 1996) are social and career (work) networks (Cotton, Shen \& Livne-Tarandach, 2011). Social and work-related networks contribute to career success, including career satisfaction, salary and promotion (Eby, Butts and Lockwood, 2003). In terms of support, SIEs rely more on social and work-related networks in the host country than do AEs, since the latter usually have already-established work-related connections (Jokinen et al, 2008; Howe-Walsh and Schyns, 2010), and a supportive expatriate social infrastructure.

Further, SIEs may more quickly lose their social capital at home, unless connected to home county nationals in the host country. Cao et al (2014) distinguished between networks of home and host country nationals, and concluded that a network of home country nationals in the host country provides career and personal support in the host country, as well as potential career opportunities back home. Tharenou and Caulfield (2010) found that SIEs who are strongly embedded in the host country through their career and social (community) networks are less likely to repatriate, although the relative importance of each type of network was not clear. SIEs may have relatively strong work-related networks, but are more likely than AEs to lack a broad social network.

H4: NZ SIEs are significantly more likely to repatriate when their networks are predominantly career-related, relative to social. 


\section{Spouse job availability in the home country}

There is a well-established literature on the impact of an expatriate's spouse on expatriate success and repatriation, with the inability of the spouse to adapt to the host country being the most common factor for expatriate failure (Andreason, 2003). Spouse job availability is most important for dual career couples, which are defined as those where "both partners are psychologically committed to their profession" (Makela, Kansala and Suutari, 2011, p.186). Expatriates who are already well settled in a host country, where their partner is also working, may find it harder to repatriate, as both partners will be concerned about finding employment in the home country. Lack of job availability for the spouse is a strong barrier to repatriation (Riusala \& Suutari, 2000), and this is exacerbated when the SIE's home country is different to that of the spouse (Maleka et al, 2011). Therefore, the availability of suitable work for the spouse of the SIE will be a potential home-country pull factor.

H5: NZ SIEs are significantly more likely to repatriate when they perceive job availability for the spouse in the home country

\section{Location of host country}

The vast majority of research on SIEs has involved developed countries (Al Ariss \& Crowley-Henry, 2013; Doherty et al, 2013a), with only recent attention paid to SIEs located in developing countries (Al Ariss and Ozbilgin, 2010), and across diverse cultural settings (Guo et al, 2013). Cross-cultural adjustment of expatriates in their host countries is important to the success of the expatriation exercise (Begley et al, 2008), and the extent and type of adjustment will depend on the cultural and psychic distance between the home and host country concerned. Sousa and Bradley (2008) argue that cultural distance is the differences in national cultures while psychic distance refers to 'the individual's perception of the differences' (p. 471). They further posit that psychic distance is an individual level construct 
while cultural distance is a national level construct, and that psychic distance is influenced by cultural distance. Based on this, we suggest that the greater the cultural distance between the home and host county, the more difficult is the SIE's adjustment, and the more likely he/she is to consider repatriation. However, Doherty et al (2011) found that SIEs may be more inclined to locate to a 'different' country for adventure and novelty, but are more likely to return home if the host country location is too different. Following this line of thought, we regard Canada, the US, and Australia ${ }^{1}$ as 'different', and Asia as 'too different' in our study. The UK is generally perceived to be the most psychically close country to New Zealand, but New Zealand SIEs usually repatriate from the UK after a period of time there (Inkson and Myers, 2003). Given these findings, we offer the following hypothesis.

H6: NZ SIEs are significantly less likely to repatriate when they are located in what are perceived as moderately psychically distant countries (Australia, Canada or USA), and more likely to repatriate when located in the too close or too far psychically countries/regions (UK or Asia).

\section{Individual SIE characteristics}

The four SIE individual characteristics that we set out to study were age, ethnicity, gender, and international experience, as these have been researched in the expatriation literature, but less so in the SIE repatriation literature. Initial descriptive analysis of these variables showed age and international experience to be highly correlated; therefore, we focused only on international experience, as the SIE literature is relatively sparse in relation to this factor. The three individual characteristics explored, therefore, were ethnicity, gender and international experience. We propose direct influences of all three SIE characteristics on intention to

\footnotetext{
${ }^{1}$ Australia is the geographically closest country, but is not generally regarded to be as psychically close to New Zealand as the UK, so could also be viewed as 'in-between'.
} 
repatriate, and moderating effects of gender and international experience on the main pull factors and intention to repatriate, as discussed below.

\section{Ethnicity (home country)}

Very little research has been conducted on the role of ethnicity in the context of self-initiated expatriation. In one of the few such studies, Al Ariss and Ozbililgin (2010) indicate that, in a host country which has substantial ethnic differences to that of an SIE, the SIE will tend to stay more closely connected to his/her established home-based networks, and may be more inclined to return if home conditions were attractive. In the case of New Zealand SIEs, those of European descent (the majority ethnicity group in New Zealand) will have closer ethnic alignment with many of the countries to which they have expatriated (US, Australia, UK, Canada) than SIEs with a minority (including indigenous) ethnicity.

H7: NZ SIEs are significantly less likely to repatriate when they are of NZ European descent (non-local majority ethnicity).

\section{Gender}

There is a scarcity of studies on gender in the SIE literature (Selmer and Lauring, 2011), with a small number of recent exceptions (e.g. Crowley-Henry and Weir, 2007; Hutchings, Michailova and Harrison, 2013; Tharenou and Caulfield, 2010; Tharenou, 2010; Thorn, 2009). There is even less research on the role of gender in SIE repatriation. Self-initiated expatriates are more gender balanced compared with AEs, which tend to be more male dominated (Doherty et al, 2011; Suutari and Brewster, 2000; Inkson and Myers, 2003), and female SIEs repatriate at the same rate as men (Tharenou, 2010), or have a similar level of repatriation intention (Hugo et al, 2003). In terms of career prioritisation, women repatriates report low career-satisfaction on returning home, even though their career satisfaction as 
expatriates was high (Biemann and Braakmann, 2013). This suggests that women may prioritise career less than other factors in their repatriation decision (Tharenou, 2010). Further, married women are more likely to repatriate to support their partner's career than their own (Tharenou, 2010), and may be more prepared than men to compromise their career prospects back home. As Tharenou $(2008,2010)$ notes, this may be for reasons of social pressure, whereby women relocating for their own career advancement is considered inappropriate.

H8: NZ SIEs are significantly more likely to repatriate when they are female

\section{Gender: moderating effects}

Historically, women are known to be more family-integrated, concerned with safety and security, and value family relations more than men (Selmer and Lauring, 2010). Men also have a higher drive for financial incentives and career building (Selmer \& Lauring, 2010). Given this, it is reasonable to propose that women are more likely to repatriate because of home country pull factors (especially lifestyle and family), and men to expatriate because of host country pull factors (economic, political and career). While SIEs in general tend to prefer work-life balance more than power-related motivators (such as money, prestige and work status), this feature is emphasised in women (Crowley-Henry and Weir, 2007; Tharenou, 2010; Thorn, 2010), suggesting that family and lifestyle would be more important for returning female SIEs than for male SIEs. Collectively, these findings provide supporting logic to the suggestion that gender may moderate the relationships between the key home country pull factors (economic opportunities, lifestyle, and relational considerations) and intention to repatriate.

H8a: When the NZ SIE is female, the positive relationship between economic opportunities in the home country and intention to return will be weakened. 
H8b: When the NZ SIE is female, the positive relationship between home country lifestyle and intention to return will be strengthened.

H8c: When the NZ SIE is female, the positive relationship between relational considerations in the home country and intention to return will be strengthened.

\section{International experience}

Overall, research on the impact of international experience among SIEs is relatively recent and sparse; results are mixed, with not enough differentiation between SIE and AE repatriates (Begley et al, 2008). This research tends to focus on the impact of level of international experience on the ability of returning expatriates to gain employment and subsequent promotion (Shaffer et al, 2012). According to Cao et al (2014), managers with international experience are more educated, and have more professional experience, and networks. Further, international experience is associated with the development of career capital (Jokinen et al, 2008; Kraimer, Shaffer and Bolino, 2009); expatriates who return expect to take on new and more demanding positions back home (Starr and Currie, 2009). However, highly internationally experienced SIEs may be more embedded in the host country environment, and less likely to repatriate (Tharenou and Caulfield, 2010) unless their expectations are met. As noted by Begley et al (2008), SIEs who repatriate find that their experience is not valued, and they tend to lack career opportunities, or face taking jobs at a lower level than that when they left their home country. We suggest that, if SIEs are aware that these possibilities exist, they will be less likely to have an intention to return.

H9: NZ SIEs are significantly less likely to repatriate when they have high international experience. 


\section{International experience: moderating effects}

Since, as outline above, the literature suggests that a highly experienced SIE has different needs and perspectives relating to repatriation compared to those of the less experienced SIE, it is reasonable to assume that international experience may moderate the key relationships associated with repatriation intention. For example, economic opportunities, lifestyle attractions and relational considerations in the home country are likely to be less important for an SIE who has gained significant international experience over a long period of time away.

H9a: When the NZ SIE has international experience, the positive relationship between economic opportunities in the home country and intention to return will be weakened.

H9b: When the NZ SIE has international experience, the positive relationship between home country lifestyle and intention to return will be weakened.

H9c: When the NZ SIE has international experience, the positive relationship between relational considerations in the home country and intention to return will be weakened.

\section{Research Methodology}

The research informed by current theoretical understanding of SIEs and SIE repatriation, which, while still in a nascent stage, is becoming more developed (Al Ariss and CrowleyHenry, 2013). As utilised by others, for example, in the conceptual framework of Tharenou and Caulfied (2010), we use the host/home country push-pull approach (Toren, 1976) to frame the questions in our investigation of SIE's repatriation. Also following other studies (e.g. Tharenou and Caulfied, 2010; Cao et al, 2014; Fatimah et al, 2013; Jackson et al 2005), we utilise 'intention to return' as our dependent variable, since intention has been wellestablished as a determinant of actual behaviour (Fishbein and Ajzen, 1975), reflecting the "psychological probability that a person will perform some behaviour that he has intended." 
(Fatimah et al, 2013, p.500). As noted by Cao et al (2014, p. 2014), "the intention to stay or repatriate has been one important outcome variable in SIE studies."

\section{Data}

The data to test the proposed conceptual model were obtained through Victoria University of Wellington's (New Zealand) Alumni internal mail system. The online web survey was sent to all the 4550 registered Alumni members. The Alumni register does not provide specific information on which of the alumni were New Zealand (citizen) expatriates, and whether they were organisational, or self-initiated. Thus, we do not have the exact number for the target population. The inability to generate sampling frames is common in online surveys (Couper, 2000, Matsuo et al., 2004). However, Matsuo et al. (2004) argue that, despite the challenges of online surveys, such as possible lack of sample representativeness, self-selection bias, and response bias, the use of online surveys has become more widespread, since it has advantages in the "speed of response, cost of distribution and speed and precision for data compilations" (p 4000). As Table 1 shows, our sample was fairly evenly spread in terms of gender, international experience and location of respondents, and was considered safe from the potential challenges of an online survey.

To identify whether an expatriate was self-initiated or organisational/assigned, relevant screening questions were incorporated into the questionnaire, allowing us to apply the relevant criteria for inclusion in the study. For example, the opening statement of the survey requested that it be completed by New Zealand citizens or permanent residency holders who were currently resident outside New Zealand. This eliminated any Alumni who were still in New Zealand and thus not current expatriates. Another question in the survey asked about their current expatriate status: whether they were working abroad, and were not sent by an employer at home (SIE), or whether they were sent abroad by their company to 
work for that organisation (AE). This approach is in line with the selection approach utilised by Tharenou and Caulfied (2010) in their study of SIEs. 95\% of the respondents identified themselves to be self-initiated expatriates, and these constituted the sample for this study. The sample thus consisted of 274 responses, out of which 248 were complete in all respects and, therefore, used for the analysis.

As Table 1 shows, the sample was spread fairly evenly across the host countries of Australia, United Kingdom, Canada/USA and Asia. $60 \%$ of the respondents were male, and ethnicity among the respondents was representative of the ethnic proportions across the country's population: New Zealand European (non-local majority ethnicity) constitute 77\% of the country's population (StatisticsNewZealand, 2013). International experience and age were also relatively evenly spread across the sample.

Table 1: Sample characteristics about here

\section{Measurement}

The questionnaire presented a number of questions relating to the demographic profile of the respondents and the dependent and independent variables of interest. The questionnaire items relating to the main constructs, which form the latent variables (economic opportunities, relational considerations and lifestyle) drew on research by Jackson et al. (2005). Jackson et al (2005) categorised the main factors influencing expatriation as political, cultural, family and economic factors. We ran exploratory factor analysis (EFA) on the political, cultural, economic and family factors. The iterative EFA process resulted in identifying three key factors which are termed economic opportunities, relational considerations and life style in this study. A similar approach has been used in the literature (Boxall, Ang \& Bartram, 2011), where EFA guides the final latent variable confirmation. A CFA was run and reported to confirm the explored factors (Table 2), as discussed later. 
The economic opportunities construct consists of 4 items, namely career opportunities, business opportunities, challenges in the work environment, and salaries. Items relating to the availability of cultural opportunities, learning for life, and ethnic mix constitute the lifestyle construct. The relational considerations construct includes items, relationships with parents and other elders, friendships and close relations with relatives. Following the approach of Jackson et al (2005), we asked respondents how they would rate the items (using a 5 point Likert-type scale) reflecting the economic/life style/relational factors at home in 'attracting them to return to New Zealand (NZ) or attracting them overseas', where $1=$ very strongly towards NZ, 2 = Strongly towards NZ, 3 = Equally towards NZ and overseas, $4=$ strongly towards overseas, and $5=$ very strongly towards overseas. The anchors measure the perceived home country pull vs push of the factors in question. The dependent variable 'intention to repatriate' (ITR) was also measured on a 5 point Likert-type scale, where respondents were asked about their intention to return: 1 being most likely to return to New Zealand, and 5 being least likely to return to New Zealand.

In the questionnaire, respondents were also asked to provide information relevant to the contextual variables (spouse job availability in the home country; the nature of their networks (social or work/career related) in the host country; and location (current host country work location - open ended). Their individual characteristics were also captured: (gender (female or male); ethnicity to which they belong (New Zealand European (non-local, majority), Maori (local, minority), Pacific Islander (non-local, minority), Asian (non-local, minority) and others - specify); international experience (number of years); and the age group to which they belong ( $<20$ years, $20-24,25-29,30-34,35-39,40-44,45-49,50-54,55-$ 59, and 60+ years). Data on all the variables, other than experience, were normally distributed; for experience, we used the natural log, which addressed the normality assumption. As age and international experience were found to be highly and significantly 
correlated, we kept only one of them (international experience) in the analysis. As $80 \%$ of the respondents classified themselves as New Zealand European, this ethnic group was compared with all other groups combined. The measurement of all the variables of interest is shown in Table 2.

Table 2 Operational Measures about here

Table 2 also shows the results of a confirmatory factor analysis (CFA) undertaken using SmartPLS (Ringle, Wende and Becker, 2014). In the CFA, the composite reliability score for each construct ranged between .71 and .83 and was within the acceptable range of 70 and 90 (Nunally and Bernstein, 1994). The convergent validity of each construct was confirmed, with all the factor loadings above .70 (except one, salaries, being .67), and average variance extracted (AVE) being more than .50. Items with factor loadings less than .70 (but more than .40) can be kept in the model if it makes theoretical sense (Hair, Hult, Ringle and Sarstedt., 2014 p.106). The data also met discriminant validity with the square root of AVE of each construct (economic opportunities .78 , life style .79 and relational considerations .85 ) being greater than its highest correlation with any other construct (Hair et al., 2014).

\section{Results}

In order to examine the incremental effect of the main latent variables and to explore potential direct and moderation effects of contextual factors and SIE individual characteristics, the study used hierarchical regression modelling. We grouped all the variables of interest into two groups: group 1) the latent variables of interest (economic opportunities, life style, relational considerations), and group 2) other variables (networks, spouse job, location, gender, international experience and ethnicity). Accordingly we tested 3 models. Model 1 tested the impact of group 2 variables. In Model 2, the latent variables (group 1) 
were added to the first model and Model 3 tested the moderating effects. This approach helped identify the incremental effects of the latent variables and moderation effects. Tables 3 and 4 summarise the correlation and regression analysis results. All the independent variables were mean centred in order to test the moderation effects, as it is a requirement to test such effects when using ModGraph (Jose, 2013). Centering reduces correlations among the independent variables of the regression model (Frazier, Tix and Barron., 2004). The correlation table shows initial signals to the results. That none of the pairwise correlations between independent variables were too high - the maximum being 0.22 - indicates a lack of multicollinearity, also evidenced by the tolerance range $(0.88-0.96)$, and VIF values $(1.04-$ 1.21) (Field and Miles, 2013).

Table 3 Pair-wise correlations

Table 4 Summary of regression results

All the tested models (Table 4) met the model fitness criteria (Field and Miles, 2013). Model 1, which includes group 2 variables (networks, spouse job, gender, international experience and ethnicity), explains $17 \%$ of the total variance of the dependent variable, intention to repatriate. The proportion of variance explained increases to $33 \%$ in Model 2, and $37 \%$ in Model 3. The $\mathrm{R}^{2}$ change in all the three models is highly significant. Highly significant $\mathrm{F}$ values demonstrate that the tested model is a strong fit to the data. Overall, all the hypothesis except $\mathrm{H} 8 \mathrm{~b}, \mathrm{H} 8 \mathrm{c}$ (moderating role of gender on lifestyle and relational considerations, respectively) and $\mathrm{H} 9 \mathrm{~b}$ (moderating role of international experience on the lifestyle were supported, as discussed below.

As shown in Model 2, each of the latent variables, namely economic opportunities, lifestyle, and relational considerations, shows a significant positive relationship with ITR. These findings endorse the existing SIE repatriation literature. Specifically, the findings 
suggest that the perceived home country pull effects of these variables significantly influence the SIEs' intention to repatriate. In other words, when economic opportunities, lifestyle and relational factors in New Zealand are perceived to be strong home country pull factors, the more likely the SIE's intention to repatriate. These findings support $\mathrm{H} 1, \mathrm{H} 2$ and $\mathrm{H} 3$.

Model 3 (Table 4) shows that all the tested relationships, except for three out of the six moderation effects hypothesised, were statistically significant. Thus, H4-H9 were supported. Three of the group 2 variables, namely gender, networks and spouse job have significant negative relationships with ITR. Considering the way these variables are defined (Table 2), the results imply that SIEs who are females, have mostly work-related, rather than social, networks in the host country, and expect spouse job availability in the home country, are more likely to repatriate than their counterparts. These findings support H8, H4 and H5, respectively. The remaining group 2 variables (location, international experience, and ethnicity) each have a positive significant relationship with ITR. Thus, SIEs who are located in Australia or Canada or USA, have 10 or more years of international experience, and who are of NZ European ethnicity, are less likely to repatriate, as compared to their counterparts. Thus, H6, $\mathrm{H} 7$ and $\mathrm{H} 9$, respectively, are supported.

Finally, we tested the hypothesised moderation effects of the selected individual characteristics on the relationships between the latent variables (economic opportunities, life style, and relational considerations) and ITR (Table 4). The moderation results that were significant were further examined by undertaking a simple slope ananlysis (Figure 1-3). The findings suggest that gender and international experience have moderation effects in the model. The gender moderation shows that the influence of economic opportunities on ITR is stronger when the SIE is female, as compared to male. Figure 1 illustrates this, showing that the regression line for females is steeper than that for males. H8a was not, therefore, supported (the result was significant but in the opposite direction). For gender, both H8b and 
H8c were not significant. On the other hand, high levels of international experience $(=>10$ years) negatively moderated the relationship between economic opportunities and ITR (Figure 2), implying that, for highly experienced people, the positive effect of economic opportunities on ITR becomes weaker; H9a was supported. Further, the the pull of relational factors was stronger for SIEs with high levels of international experience, compared with less experienced SIEs; this is evident from the steeper slope of the regression line for high international experience (Figure 3). H9c was not, therefore, supported (the result was significant but in the opposite direction); H9b was not significant. Table 5 shows a summary overview of the findings.

Table 5: Summary Overview of Findings about here

\section{Discussion}

Our findings show that the conditions favouring SIE's intentions to repatriate are when the SIE is female, has stronger work-related, compared with social, networks abroad, and when there is perceived job availability for the spouse in the home country. Conversely, conditions favouring the intention to remain in the host country are when the SIE has high international experience $(=>10 \mathrm{yrs})$, is of NZ European ethnicity and is located in the following host countries: Australia, Canada or USA. Our findings also reveal the moderating influences of gender and international experience on the relationships between the home country pull factors (economic, lifestyle, and relational) and SIEs' intention to repatriate. We now reflect on these findings.

First, we discuss the direct effects hypothesised, including the home country pull factors established in the literature (economic, lifestyle, and relational), and then the contextual factors are discussed (spouse job availability in the home country, the nature of the SIEs' host country networks, and host country location). Our discussion then focuses on the 
direct and moderation effects of the three individual characteristics (gender, international experience, and ethnicity) on the relationships between the three established pull factors and intention to repatriate. We highlight the findings that we believe are novel, and offer some tentative explanations.

$\mathrm{H} 1-\mathrm{H} 3$ focused on the main home country pull variables known to have significant influences on repatriation decisions of SIEs: economic opportunities, lifestyle and relational factors. Consistent with others' findings (e.g. Carr et al, 2005; Jackson et al, 2005; Doherty et al, 2011; Inkson et al 2004), we found that all three variables were positively related to SIE's intentions to repatriate. Our results are thus in line with similar findings on the home country pull effect of economic factors (e.g. Al Ariss and Ozbililgin, 2010; Richardson and McKenna, 2006), lifestyle factors (e.g. Selmer and Lauring, 2010), and relational considerations (e.g. Inkson et al, 2004; Hugo et al, 2003). While H1-H3 all support existing literature, these findings add support to the small body of research on SIE repatriation, addressing calls for more research studies on this topic.

Given the acknowledged importance of contextual factors in SIE research (Al Ariss and Crowley-Henry, 2013; Doherty et al, 2013), we also examined the direct impact of three contextual factors (work-related versus social host country networks, spouse job availability, and host country location) on SIEs' intention to repatriate (H4-H6). With regard to the role of networks (H4), existing research indicates that social networks play an important role in the adjustment of SIEs in their host countries (Froese, 2012; Tharenou and Caulfield, 2010). Even though career networks are important for SIEs, host country social networks provide much-needed psychosocial support (Shen and Kram, 2011); this is especially important for SIEs, who, in contrast to AEs, do not generally have home-based organisational support. Together with the finding that expatriates require psychosocial support in the host country (such as friendship, emotional support, and stability) more than career support (Shen and 
Kram, 2011), this suggests that, even though the SIE may have career/work-related networks, the lack of social networks may strengthen an SIE's intention to repatriate. In keeping with this, our results showed that strong work-related networks were insufficient to motivate SIEs to stay in the host country, when social networks were not strong. This is consistent with the finding of Tharenou and Caulfield (2010) that weak host country embeddedness was a push factor for SIEs to return home, although these authors did not differentiate between career and community networks. Our findings suggest that social networks in the host country may be more important in the decision to stay than work/career- related networks.

While job availability for the spouse in the host country (H5) is known to influence the decision of AEs to expatriate, as well as the success of the expatriation assignment (Andreason, 2003), we have demonstrated that this is also an important factor for SIEs intending to return home. When considered in the light of dual career couples who have expatriated together, and where both partners are actively pursuing career opportunities, there is still relatively little research (exceptions include Harvey and Wiese, 1998; Selmer and Lauring, 2011.) Although our study does not differentiate between dual career couples and those where the spouse simply seeks a job, it is logical to suggest that job (or career) availability for the spouse is important in the SIE's intention to repatriate. Extending the existing expatriate research, our findings highlight the need for job availability for both partners in the home country to support repatriation intention of SIEs.

Our finding concerning host country location (H6) is interesting, and not readily explicable. We hypothesised that psychic similarity (as generally perceived) between the home and host country might play a role, and this is partially supported by the findings; but it does not explain the result for SIEs located in the UK. We see that, as hypothesised, the closest and furthest host countries in terms of psychic distance (UK and Asia) are both associated with an SIE's intention to return, while the in-between countries, Canada, USA, 
and Australia are associated with intention to remain. Other studies on New Zealand SIEs found that Australia is often chosen as a location that is close to home, but these SIE's have little intention to return to New Zealand (Inkson et al 2004; Jackson et al, 2005); this is explained by economic prospects being generally better, and lifestyle and cultural aspects being similar. The UK is often a major destination for New Zealanders, as part of their overseas experience, but, as Inkson and Myers (2003) note, SIEs will usually have an expectation to return to New Zealand to bring up children (for lifestyle and education reasons), or retire. Given that SIEs have considerable agency in host country choice, intention to repatriate or stay after a predetermined time may be factored into their initial choice of host country, as Inkson and Myers (2003) have demonstrated in the case of the UK.

We also investigated the direct relationships between three individual characteristics and SIEs' intention to return home (H7-9), as well as their moderating effects. With respect to ethnicity (H7), while this has been well researched in the migration literature ( $\mathrm{Al}$ Ariss and Ozbililgin, 2010), relatively little work has been conducted on its impact in SIE expatriation and repatriation intentions. We found that SIEs of non-local (majority) ethnicity (New Zealand European) are less likely to repatriate than those of the minority local (and other) ethnicities. This is not unexpected, and is in line with Al Ariss and Ozbililgin (2010), who suggest that people of local and minority ethnicities are more easily drawn back because of difficulties fitting into their host country environments. However, our findings regarding ethnicity must be regarded with some caution, as the sample, while reflecting the ethnic proportions of the population, was dominated by non-local (New Zealand European) respondents, which may impact our findings. What is clear from this and the existing literature, is that a better understanding of SIE repatriation among ethnic groups is important. With regard to gender (H8), our finding that females are more likely than males to repatriate is in line with much of the literature (Tharenou, 2010), the rationale being that 
women are drawn more strongly than men by lifestyle and relational factors (Thorn, 2010). This has generally been attributed to the findings from the psychology literature, which show men depicted as being more goal oriented and focused more on mastering (career), while women are driven by affiliation and inter-personal concerns (family and relationships) (Gove, 1994). However, when the moderation effects of gender are considered, the findings are contrary to those expected (H8a-8c). Following the line of argument presented above that women are more concerned about family and relationships, we had hypothesised that 'female' would positively moderate the lifestyle and relational influences on intention to repatriate. However, we found no significant results for these hypothesised moderation effects. While contrary to the advanced logic, Selmer and Lauring (2010) found no gender difference among SIEs relating to family, regardless of women being considered to value affiliation more than men, providing some support for our findings. We also hypothesised that being female would negatively influence the relationship between economic factors and intention to return, but found the opposite effect: home country economic opportunities had a stronger pull effect towards home for females than for males. This can partly be explained by the finding of Hugo et al (2003) that women are as equally concerned as men about career opportunities, which, by inference, could also refer to economic opportunities more broadly. A further explanation may derive from the view that the earlier work on female SIEs has tended to overlook the increasing role of women in the workplace (Kooij, Lange, Jansen \& Dikker, 2008), and the importance of economic factors in their location decision. In summary, our findings on gender effects suggest that career and economic drivers may be increasing in importance for women SIEs, and this is only recently being identified in the literature. The role of gender on SIE repatriation undoubtedly warrants further research.

Regarding international experience (H9), our results show that SIEs with high levels of international experience $(=>10 \mathrm{yrs})$ are less likely to repatriate than those with less 
international experience. This is a new finding, and is consistent with the logic that internationally experienced SIEs more easily secure jobs in a foreign market (Shaffer et al, 2012), and would, therefore, be less likely to repatriate. Further, it has been argued that the longer the time that SIEs spend time away from the home country, the more likely that their home-based networks and relationships will weaken or be lost, thus making it harder to return (Cao et al, 2014). Conversely, in reporting the moderation effects (H9a-H9c), the negative moderation effect of this variable suggests that perceptions of increasing economic opportunities in the home country do not motivate highly experienced SIEs to repatriate. This could be explained in several ways. For example, with international experience enhancing cross-cultural adjustment (Moon, Choi \& Jung, 2012), these SIEs appear to be committed to remain abroad and pursue career goals. Or, as reported by Begely et al (2008) and others, returning expatriates find that their international experience is not valued, and thus not reflected in the employment opportunities offered. On the other hand, the pull of relational considerations to repatriate is strengthened for SIEs with greater international experience, as shown by the positive moderation effect. Thus, it can be argued that the longer an expatriate spends abroad, the more they miss family and friends back home, and/or the more are the family pressure on them to return.

In summary, our findings on the moderation effects by the SIEs' individual characteristics, gender and international experience, on the relationships between the established home country pull factors and intention to repatriate are not, to our knowledge, reported elsewhere. These findings suggest that, even though home country pull factors positively influence SIEs' intentions to repatriate, the pull effect may be strengthened or weakened by other factors of an individual nature. These findings address the recent call in the literature for distinctions between structural and individual factors in expatriation research, and the need for a finer-tuned approach to understanding the drivers of repatriation 
(Doherty et al, 2011). In addition, the literature to date has been sparse on the impact of host country location and ethnicity on SIE repatriation, and, to our knowledge, have not been tested together in previous studies of SIE repatriation intention. We propose that these factors add to the set of home and host country pull and push factors which appear to influence the repatriation decision of SIEs.

\section{Conclusions and Implications}

Our study set out to examine the factors influencing the intention of New Zealand selfinitiated expatriates to return home. Considerable research has been conducted on the consequences and outcomes of repatriation, mainly in the AE context, with some recent work being conducted on outcomes associated with SIE repatriation (Begley et al, 2008). However, far less has been published on SIE's intention to repatriate, and it is to this body of literature that our study contributes.

Three main contributions arise from this study. First, by confirming the positive impact of the perceived home country pull of economic opportunities, lifestyle benefits, and relational links on SIEs' intention to repatriate, we lend support to the current, but limited, literature on SIE repatriation, addressing a noted need in the literature (Doherty et al 2013a). Second, we contribute to this literature by identifying several contextual variables and individual SIE characteristics which represent additional home country pull and host country push factors influencing repatriation intent. As already noted, the literature to date has been sparse on reporting the impact of several of these additional influencing variables. For example, Al Ariss \& Crowley-Henry (2013) argue for more studies to be conducted on gender and diversity (emphasising minority groups) in SIE research. Both gender and ethnicity were shown to be important SIE individual characteristics influencing repatriation intention in our study, supporting the need for additional research on these factors. Third, our 
study provides some insights into the complexity of the influences on repatriation intention by identifying three moderation effects by SIE individual characteristics that have not been noted before. This highlights new and interesting findings, supporting the contention that SIE research reflects a complex and multidimensional phenomenon worthy of considerably more research (Al Ariss and Crowley-Henry, 2013). Our study adds to the debate on the conceptualisation of self-initiated repatriation, by including direct and indirect effects of contextual variables and individual characteristics. We, therefore, extend earlier findings that have mainly examined single and less complex relationships.

The study raises a number of implications for both theory and practice. In terms of theory, the domain of SIE and SIE repatriation research continues to lack sound conceptualisation and theoretical location (Doherty et al, 2013). Although mostly well studied in the $\mathrm{AE}$ repatriation literature, areas requiring further validation and research in terms of SIE repatriation include: the impact of dual career couples on intention to return (Selmer and Lauring, 2011), the role of family and children in this decision (Van der Velde, Bossink, and Jansen, 2005), the impact of social and work-related networks, as well as considerations of gender and ethnicity on the intention of SIEs to repatriate. In terms of contextualisation, country context is an important consideration. Decisions made by SIEs are context (country) bound, since attractiveness of push and pull factors is a relative concept, depending on the particular host and home countries involved (Guo et al 2013). However, seldom are the relative impacts of these factors considered; for example, home country lifestyle benefits may be seen as attractive when compared to some host countries, but not when compared to others. We support other researchers (e.g. Al Ariss and Crowley-Henry, 2014) in arguing that the interplay between home and host country contexts needs further investigation; this also extends to a need for developed vs. developing country contexts (Al Ariss and Ozbililgin, 2010). 
For practitioners, including government agencies, HR managers and SIEs themselves, the findings highlight key repatriation influences, and also provide a deeper understanding of the influence of contextual factors (availability of spouse job, social vs work-related networks, and host country location) and SIE individual characteristics (gender, ethnicity and international experience) on these. It behoves human resource managers, particularly those involved in repatriating self-initiated, rather than organisational expatriates (Howe-Walsh and Schyns, 2010) to understand the influences on SIE repatriation to ensure that employment conditions support successful repatriation outcomes. When government policy is concerned with attracting talent back into the economy, an understanding of the factors that influence an SIE to repatriate is critical. Given that $65 \%$ of expatriates in the Western world are selfinitiated (Doherty, Dickmann and Mills, 2008), the onus on attracting expatiates to return to their home country is perhaps swinging away from the organisations that have traditionally assigned expatriates, and more towards industry and national initiatives to bring SIE talent back. This highlights the need for a deeper knowledge of the multi-level and multi-faceted nature of the SIE repatriation phenomenon (Al Ariss and Crowley-Henry, 2013; Doherty et al, 2013a).

As with any research, this study has several limitations. Our data sample was from only one country, which limits the opportunity to generalise home country factors that may influence SIEs. Limitations associated with online survey research, as highlighted by Matsuo et al (2004), such as self-selection, non-response bias, and lack of control over the testing environment also apply to this research, although measures were taken to mitigate potential impacts resulting from this approach. Although we were interested in specifically examining intention to return, longitudinal studies of those SIEs who actually repatriated (following, for example, the approach of Tharenou and Caulfield, 2010) would shed further light on how intentions are followed through. Moreover, the repatriation decision may also be dependent 
on expatriate's level of lifecourse and the need for longitudinal studies. on Finally, while our study indicated that additional factors and interactions played a role in SIE intention to repatriate, these findings require validation, as well as in-depth qualitative investigation, in order to better understand how and why these factors impact an SIE's intention to repatriate. 


\section{References}

Al Ariss, A. (2010), 'Modes of engagement: Migration, self-initiated expatriation and career Development,' Career Development International, 15, 338-358.

Al Ariss, A. and Ozbilgin, M. (2010), "Understanding self-initiated expatriation: career experience of Lebanese self-initiated expatriates in France", Thunderbird International Business Review, 52 (4), 275-85.

Al Ariss, A. and Crowley-Henry, M. (2013). Self-initiated expatriation and migration in the management literature: Present theorizations and future research directions. Career Development International, 18(1), 78-96.

Altman, Y., \& Baruch, Y. (2012). Global self-initiated corporate expatriate careers: a new era in international assignments? Personnel Review, 41(2), 233-255.

Andreason, A. W. (2003). Expatriate adjustment to foreign assignments. International Journal of Commerce \& Management, 13(1), 42-60.

Andresen, M., Bergdolt, F., Margenfeld, J., \& Dickmann, M. (2014). Addressing international mobility confusion - developing definitions and differentiations for self-initiated and assigned expatriates as well as migrants. The International Journal of Human Resource Management, 25(16), 2295-2318.

Arthur, M. and Rousseau, D. (eds) (1996), The Boundaryless Career: A New Employment Principle for a New Organizational Era, Cambridge University Press, Boston, MA

Baruch, Y., Budhwar, P.S. and Khatri, N. (2007), Brain drain: inclination to stay abroad after studies, Journal of World Business, 42 (1), 99-112.

Begley, A., Collings, D. G., and Scullion, H. 2008. The cross-cultural adjustment experiences of selfinitiated repa- triates to the Republic of Ireland labour market. Employee Relations, 30: 264-282.

Biemann, T., and Andresen, M. (2010), 'Self-initiated foreign work experience versus expatriate assignment: A distinct group of international careerists?' Journal of Managerial Psychology, 25, 430-448

Biemann, T., \& Braakmann, N. (2013). The impact of international experience on objective and subjective career success in early careers. The International Journal of Human Resource Management, 24(18), 3438-3456.

Cao, L., Hirschi, A., \& Deller, J. (2014). Perceived organizational support and intention to stay in host countries among self-initiated expatriates: the role of career satisfaction and networks. The International Journal of Human Resource Management, 25(14), 2013-2032.

Carr, S. C., Inkson, K., \& Thorn, K. (2005). From global careers to talent flow: Reinterpreting "brain drain." Journal of World Business, 40(4), 386-398.

Cotton, R., Shen, Y. and Livne-Tarandach, R. (2011), On becoming extraordinary: the content and structure of the developmental networks of major baseball hall of famers, Academy of Management Journal, 54 (1), 15-46

Couper, M.P. (2000), 'Web surveys a review of issues and approaches,' Public Opinion Quarterly, 64, 4, 464-494.

Crowley-Henry, M. and Weir, D. (2007), “The international protean career: four women's narratives", Journal of Organizational Change Management, Vol. 20 No. 2, pp. 245-58.

Doherty, N., Dickmann, M., \& Mills, T. (2008). Career activities or active careerists. Paper presented at $24^{\text {th }}$ EGOS Colloquium, Amsterdam, July 10-12.

Doherty, N., Dickmann, M., \& Mills, T. (2011). Exploring the motives of company-backed and selfinitiated expatriates. The International Journal of Human Resource Management, 22 (3), 595-611.

Doherty, N. T., \& Dickmann, M. (2012). Measuring the return on investment in international assignments: An action research approach. The International Journal of Human Resource Management, 23 (16), 3434-3454.

Doherty, N., Richardson, J., \& Thorn, K. (2013). Self-initiated expatriation: Career experiences, processes and outcomes. Career Development International, 18 (1), 6-11.

Doherty, N., Richardson, J., \& Thorn, K. (2013a). Self-initiated expatriation and self-initiated expatriates: Clarification of the research stream. Career Development International, 18 (1), $97-$ 112. 
Eby, L. T., Butts, M., \& Lockwood, A. (2003). Predictors of success in the era of the boundaryless career. Journal of Organizational Behavior, 24, 689-708

Fatimah, S., Yusliza, \& Surienty, L. (2013). You are kind, you are smart, and you are important : The linkages between individual factors and the intention to repatriate among Malaysian self-initiated expatriates. Journal of Social and Development Sciences, 4(11), 498-507.

Field, A. and Miles, J. (2013) Discovering Statistics Using IBM SPSS Statistics London, Sage.

Fishbein, M. \& Ajzen, I. (1975). Belief, attitude, intention and behaviour: An introduction to theory and research. (D. C. Park \& L. L. Liu, Eds.) Reading MA Addison Wesley (p. 480). AddisonWesley.

Frazier, P. A., Tix, A. P., \& Barron, K. E. (2004). Testing moderator and mediator effects in counseling psychology research. Journal of Counseling Psychology, 51 (1), 115-134.

Froese, F. J. (2012). Motivation and adjustment of self- initiated expatriates: The case of expatriate academics in South Korea. International Journal of Human Resource Management, 23 (6), 10951112.

Gove, W. R. (1994). Why we do what we do: A biopsychosocial theory of human motivation. Social Forces, 73(2), 363-394.

Guo, C., Porschitz, E. T., \& Alves, J. (2013). Exploring career agency during self-initiated repatriation: A study of Chinese sea turtles. Career Development International, 18 (1), 34-55.

Hair, J. F., Hult, G. T. M., Ringle, C. M. and Sarstedt, M. (2014) 'A Primer on Partial Least Squares Structural Equations Modelling (PLS-SEM)', California, SAGE Publications.

Harvey, M. and Wiese, D. (1998). The dual-career couple: female expatriates and male trailing spouses, Thunderbird International Business Review, 40, 359-88

Howe-Walsh, L., \& Schyns, B. (2010). Self-initiated expatriation: Implications for HRM. The International Journal of Human Resource Management, 21(2), 260-273.

Hugo, G., Rudd, D., \& Harris, K. (2003). Australia's diaspora: Its size, nature and policy implications. Canberra: Committee for Economic Development of Australia.

Hutchings, Michailova \& Harrison (2013). Neither ghettoed nor cosmopolitan: A study of Western women's perceptions of gender and cultural stereotyping in the UAE. Management International Review, 53: 291-318

Inkson, K., \& Myers, B., A. (2003). The big OE: Self-directed travel and career development. Career Development International, 8 (4), 170-181.

Inkson, K., Carr, S. C., Edwards, M., Hooks, J., Jackson, D., Thorn, K., \& Allfree, N. (2004). From brain drain to talent flow. University of Auckland Business Review, 6 (2): 29-39.

Inkson, K. and Richardson, J. (2010), Self-initiated expatriation and career development: diversity across culture and genders, Symposium proposal at the 2010 Academy of Management Annual Conference, Montreal, Canada.

Jackson, D. J. R., Carr, S. C., Edwards, M., Thorn, K., Allfree, N., Hooks, J., \& Inkson, K. (2005). Exploring the dynamics of New Zealand's talent flow. New Zealand Journal of Psychology, 34 (2), 110-116.

Jokinen, T., Brewster, C., \& Suutari, V. (2008). Career capital during international work experiences: contrasting self-initiated expatriate experiences and assigned expatriation. The International Journal of Human Resource Management, 19 (6), 979-998.

Jose, P. E. (2013). Modgraph-I: A Programme to Compute Cell Means for the Graphical Display of Moderation Analysis: The Internet Version, Version 3.0. Victoria University of Wellington, New Zealand. Retrieved July 2013 from Http://Pavlov.Psyc.Vuw.Ac.Nz/Paul-Jose/Modgraph/

Junaimah, J. \& Yusliza, M. Y. (2011). Brain drain: Propensity to leave by Malaysian professionals. International Journal of Innovation, Management and Technology, 2(2), 119-122.

Kazlauskienè, A., \& Rinkevičius, L. (2006). Lithuanian "brain drain" causes: Push and pull factors. Engineering economics, 1 (46), 27-37.

King, R. (2000). Generalizations from the history of return migration. In B. Ghosh (Ed.), Return migration: 7-45. Geneva: United Nations.

Kooij, D., Lange, A., Jansen, P., \& Dikker, J. (2008). Older workers' motivation to continue to work: A conceptual review. Journal of Managerial Psychology, 23 (4), 364-394. 
Kraimer, M. L., Shaffer, M. A., \& Bolino, M. C. (2009). The influence of expatriate and repatriate experiences on career advancement and repatriate retention. Human Resource Management, 48 (1), 27-47.

Lidgard, J., \& Gilson, C. (2002). Return migration of New Zealanders: Shuttle and circular migrants. New Zealand Population Review, 28, 99-128

Makela,L., Kansala, M., \& Suutari, V. (2011). The roles of expatriates' spouses among dual career couples. Cross Cultural Management: An International Journal, 18 (2): 185-197.

Matsuo, H., McIntyre, K. P., Tomazic, T., \& Katz, B. (2004). The online survey: Its contributions and potential problems. ASA Proceedings of the Section on Survey Research Methods, 27: 3998-4000.

Moon, H. K., Choi, B. K., \& Jung, J. S. (2012). Previous international experience, cross-cultural training, and expatriates' cross-cultural adjustment: Effects of cultural intelligence and goal orientation. Human Resource Development Quarterly, 23 (3), 285-330.

National Business Review (2010). Network aims to put expatriates to work for New Zealand. April 1.

Nunally, J. C., \& Bernstein, I. 1994. Psychometric Theory. New York: McGraw-Hill.

Richard, J., \& Zikic, J. (2007). The darker side of an international academic career. Career Development International, 12 (2), 164-186.

Richardson, J., and McKenna, S. (2006), Exploring relationships with home and host countries: A study of self-directed expatriates, International Journal of Cross Cultural Management, 13, 6-22.

Ringle, C. M., Wende, S. and Becker, J.-M. (2014) 'Smartpls 3', Hamburg. Retrieved from http://www.smartpls.com, SmartPLS.

Riusala, K. and Suutari, V. (2000), Expatriation and careers: perspectives of expatriates and spouses, Career Development International, 5, 81-90.

Selmer, J., \& Lauring, J. (2010). Self-initiated academic expatriates: Inherent demographics and reasons to expatriate. European Management Review, 7 (3), 169-179.

Selmer, J., \& Lauring, J. (2011). Marital status and work outcomes of self-initiated expatriates: Is there a moderating effect of gender? Cross Cultural Management: An International Journal, 18 (2), 198-213.

Shaffer, M. A., Kraimer, M. L., Chen, Y.-P., \& Bolino, M. C. (2012). Choices, challenges, and career consequences of global work experiences: A review and future Agenda. Journal of Management, 38 (4), 1282-1327.

Shen, Y., \& Kram, K. E. (2011). Expatriates' developmental networks: Network diversity, base, and support functions. Career Development International, 16(6), 528-552.

Sousa, C. M. P. \& Bradley, F. (2008) Cultural distance and psychic distance: Refinements in conceptualization and measurement. Journal of Marketing Management 24(5-6): 467-488.

Sriskandarajah, D., and Drew, C. (2006), Brits Abroad: Mapping the Scale and Nature of British Emigration, London: Institute for Public Policy Research

Stahl, G.K. (1998), Internationaler Einsatz von Fu "hrungskra "ften, Munich: Oldenbourg

Starr, T. L., \& Currie, G. (2009). "Out of sight but still in the picture": Short-term international assignments and the influential role of family. International Journal of Human Resource Management, 20, 1421-1438

StatisticsNewZealand 2013. Demographic trends: 2012. available from www.ststs.govt.nz

Suutari, V. \& Brewster, C. (2000), "Making their own way: international experience through selfinitiated foreign assignments", Journal of World Business, 35, 417-36.

Tharenou, P. (2008). Disruptive decisions to leave home: Gender and Family differences in expatriation choices? Plz Val see fixing this reference?

Tharenou, P. (2010). Women's self-initiated expatriation as a career option and its ethical issues. Journal of Business Ethics, 95(1), 73-88.

Tharenou, P., \& Caulfield, N. (2010). Will I stay or will I go ? Self-initiated expatriates. Academy of Management Journal, 53 (5), 1009-1028.

Thorn, K. (2009), "The relative importance of motives for international self-initiated mobility", Career Development International, 14 (4-5), 441-64.

Toren, N. 1976. Return to Zion. Social Forces, 54, 546-558.

Ushkalov, I. G., \& Malakha, I. A. (2001). The "brain drain" as a global phenomenon and its characteristics in Russia. Russian Social Science Review, 42 (5), 79-95. 
Van der Velde, M. E. G., Bossink, C. J. H., \& Jansen, P. G. W. (2005). Gender differences in the determinants of the willingness to accept an international assignment. Journal of Vocational Behavior, 66 (1), 81-103. 
Table 1: Sample Characteristics $(n=274)$

\begin{tabular}{|l|l|}
\hline Gender & Male 60\%, Female 40\% \\
\hline Ethnicity & New Zealand European 80\%, Others 20\% \\
\hline Age (years) & $20-29=12 \%, 30-39=32 \%, 40-49=27 \%, 50-59=16 \%, 60+=13 \%$ \\
\hline $\begin{array}{l}\text { International experience } \\
\text { (years) }\end{array}$ & $\leq 5=27 \%, 5-10=21 \%, 11-20=29 \%, \geq 20=23 \%$ \\
\hline $\begin{array}{l}\text { Current geographic } \\
\text { location }\end{array}$ & $\begin{array}{l}\text { Australia 29\%, UK 27\%, Canada/USA 16\%, Asia 15\%, Rest of the World } \\
13 \%\end{array}$ \\
\hline
\end{tabular}

Table 2: Operational Measures of the Explanatory Variables

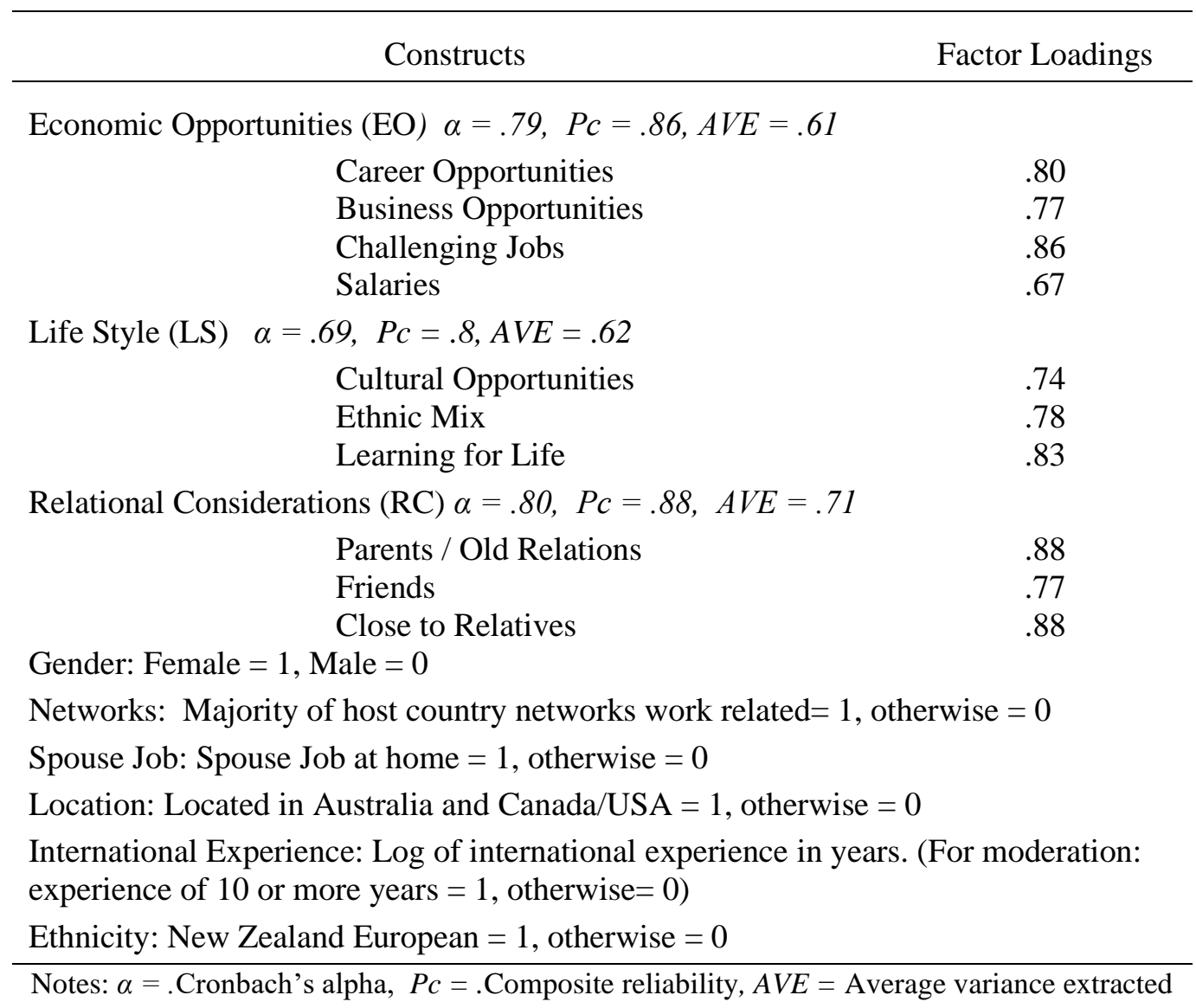


Table 3: Pair Wise Correlations $(n=248)$

\begin{tabular}{|c|c|c|c|c|c|c|c|c|c|c|c|c|c|}
\hline \multicolumn{2}{|c|}{ VARIABLES } & \multirow{2}{*}{$\frac{1}{1}$} & \multirow[t]{2}{*}{2} & \multirow[t]{2}{*}{3} & \multirow[t]{2}{*}{4} & \multirow[t]{2}{*}{5} & \multirow[t]{2}{*}{6} & \multirow[t]{2}{*}{7} & \multirow[t]{2}{*}{8} & \multirow[t]{2}{*}{9} & \multirow[t]{2}{*}{10} & \multirow{2}{*}{$\frac{\text { Mean }}{3.32}$} & \multirow{2}{*}{$\frac{\mathrm{SD}}{1.03}$} \\
\hline 1 & Intention to Repatriate & & & & & & & & & & & & \\
\hline 2 & Gender & $-0.15^{* *}$ & 1 & & & & & & & & & 0.00 & 0.49 \\
\hline 3 & Networks & $-0.16^{* *}$ & $-0.21 * * *$ & 1 & & & & & & & & 0.00 & 0.50 \\
\hline 4 & Spouse Job & $-0.11 *$ & -0.07 & $-0.13 *$ & 1 & & & & & & & 0.00 & 0.46 \\
\hline 5 & Location & $0.25 * * *$ & -0.05 & -0.07 & 0.09 & 1 & & & & & & 0.00 & 0.50 \\
\hline 6 & International Experience & $0.24 * * *$ & $-0.18 * * *$ & 0.08 & -0.04 & 0.08 & 1 & & & & & 0.00 & 0.50 \\
\hline 7 & Ethnicity & $0.15^{* *}$ & -0.08 & 0.05 & 0.08 & $0.16^{* *}$ & $0.22 * * *$ & 1 & & & & 0.00 & 0.40 \\
\hline 8 & Relational Considerations & $0.38 * * *$ & -0.08 & -0.05 & 0.05 & $0.19 * * *$ & $0.10^{*}$ & $-0.12 *$ & 1 & & & 0.00 & 1.00 \\
\hline 9 & Life Style & $0.28 * * *$ & 0.07 & $-0.16^{* *}$ & -0.02 & 0.06 & 0.02 & $-0.13^{*}$ & 0.01 & 1 & & 0.00 & 1.00 \\
\hline 10 & Economic Opportunities & $0.13 * *$ & $-0.18 * * *$ & $0.21 * *$ & -0.10 & -0.07 & 0.05 & -0.08 & 0.05 & 0.02 & 1 & 0.00 & 1.00 \\
\hline
\end{tabular}


Table 4: Summary of Regression Results

\begin{tabular}{|c|c|c|c|}
\hline \multirow{2}{*}{$\begin{array}{l}\text { Dependent Variable: } \\
\text { Intention to Repatriate }\end{array}$} & \multicolumn{3}{|c|}{ Coefficient Estimates } \\
\hline & Model 1 & Model 2 & Model 3 \\
\hline Intercept & $3.36^{* * *}$ & $3.36 * * *$ & $3.36 * * *$ \\
\hline Gender & $-0.33 * *$ & $-0.26^{*}$ & $-0.22 *$ \\
\hline Networks & $-0.43 * * *$ & $-0.37 * * *$ & $-0.35 * * *$ \\
\hline Spouse Job & $-0.36^{* *}$ & $-0.35 * *$ & $-0.38 * * *$ \\
\hline Location & $0.43 * * *$ & $0.29 * *$ & $0.28 * *$ \\
\hline International Experience & $0.36^{* *}$ & $0.27 * *$ & $0.27 * *$ \\
\hline Ethnicity & 0.21 & $0.32 *$ & $0.36^{* *}$ \\
\hline Relational Considerations (RC) & & $0.33 * * *$ & $0.35 * * *$ \\
\hline Life Style (LS) & & $0.22 * * *$ & $0.21 * * *$ \\
\hline Economic Opportunities (EO) & & $0.12^{*}$ & $0.12 * *$ \\
\hline EO*Gender & & & $0.25^{*}$ \\
\hline EO*Int. Experience & & & $-0.21 *$ \\
\hline RC*Gender & & & .170 \\
\hline RC*Int. Experience & & & $0.32 * *$ \\
\hline LS*Gender & & & -.07 \\
\hline LS*Int. Experience & & & -.097 \\
\hline Model Fit Statistics & & & \\
\hline Adjusted $\mathrm{R}^{2}$ & 0.17 & 0.33 & 0.37 \\
\hline F Value & $9.20 * * *$ & $14.54 * * *$ & $10.77 * * *$ \\
\hline $\mathrm{R}^{2}$ Change & 0.19 & 0.17 & 0.06 \\
\hline F Change & $9.20 * * *$ & $20.72 * * *$ & $3.64 * *$ \\
\hline
\end{tabular}

Significance Levels: $* * *=.001, * *=.01, *=.05$

Table 5: Overview of Findings

\begin{tabular}{|c|c|c|c|}
\hline Factor & Hypothesis & $\begin{array}{c}\text { Likelihood to } \\
\text { Return }\end{array}$ & Moderation by: \\
\hline \multicolumn{4}{|l|}{ Established Pull Factors } \\
\hline EO (home country) & H1 & More likely & $\begin{array}{l}\text { Gender, International } \\
\text { Experience }\end{array}$ \\
\hline LS (home country) & $\mathrm{H} 2$ & More likely & No Moderation Found \\
\hline RC (home country) & $\mathrm{H} 3$ & More likely & International Experience \\
\hline \multicolumn{4}{|l|}{ Contextual Factors } \\
\hline $\begin{array}{l}\text { Networks (host country): Mostly work } \\
\text { related rather than social }\end{array}$ & $\mathrm{H} 4$ & More likely & Not tested \\
\hline Spouse Job (home country) availability & H5 & More likely & Not tested \\
\hline $\begin{array}{l}\text { Location (host country): Australia and } \\
\text { Canada/USA compared to UK and Asia }\end{array}$ & H6 & Less Likely & Not tested \\
\hline Individual Characteristics & & & \\
\hline $\begin{array}{l}\text { Ethnicity (home country): Non-local } \\
\text { majority - New Zealand European }\end{array}$ & $\mathrm{H} 7$ & Less Likely & Not tested \\
\hline Gender: Female & $\mathrm{H} 8$ & More likely & NA \\
\hline International Experience: High & $\mathrm{H} 9$ & Less Likely & NA \\
\hline
\end{tabular}


Figure 1: Moderation Effects of Gender on the Relationship between Economic Opportunities and Intention to Repatriate

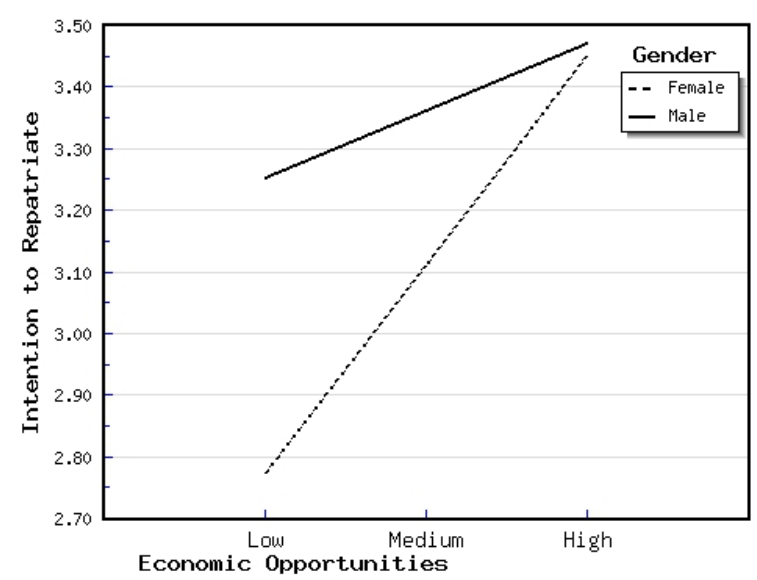

Figure 2: Moderation Effects of International Experience on the Relationship between Economic Opportunities and Intention to Repatriate

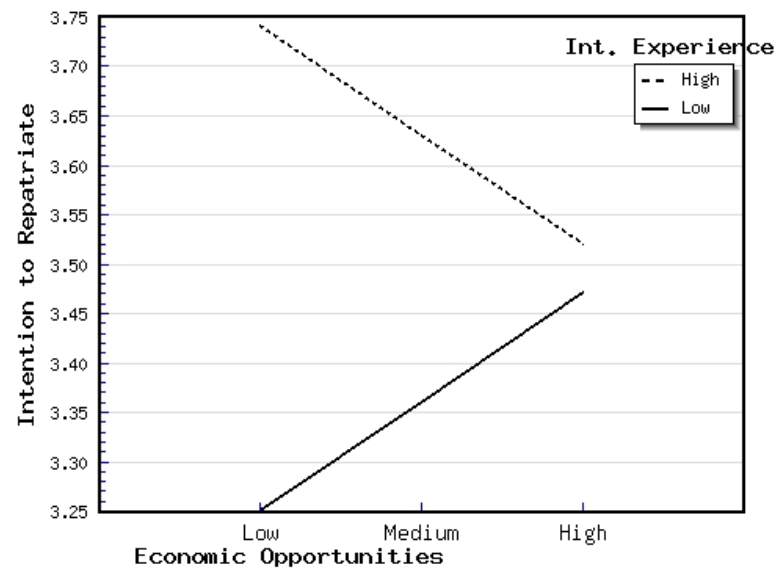

Figure 3: Moderation Effects of International Experience on the Relationship between Relational Considerations and Intention to Repatriate

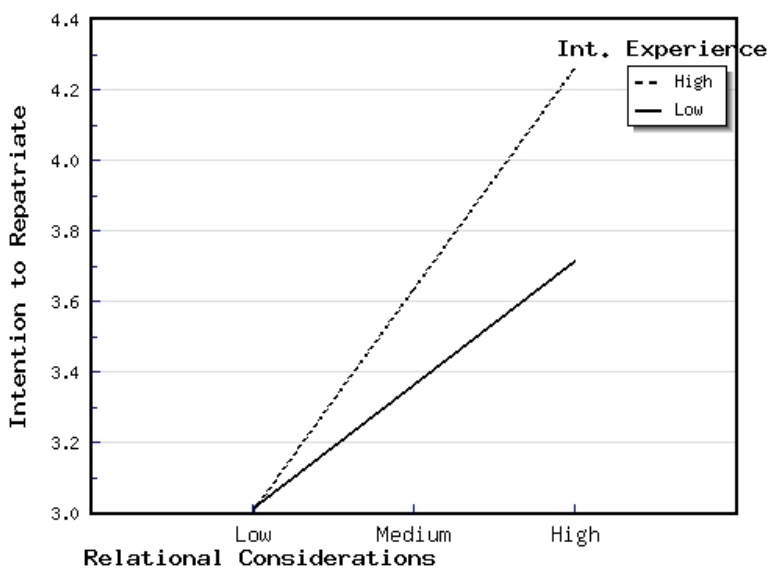

